Quantifying the spatial distribution and trends of supplementary feeding sites in South Africa and their potential contribution to vulture energetic requirements

Brink, C. W.

2020-10

Brink , C W , Santangeli , A , Amar , A, Wolter , K, Tate , G, Krüger , S, Tucker , A S \&

Thomson, $R L 2020$, ' Quantifying the spatial distribution and trends of supplementary feeding sites in South Africa and their potential contribution to vulture energetic requirements ' , Animal Conservation , vol. 23 , no. 5 , pp. 491-501 . https://doi.org/10.1111/acv.12561

http://hdl.handle.net/10138/320389

https://doi.org/10.1111/acv.12561

unspecified

acceptedVersion

Downloaded from Helda, University of Helsinki institutional repository.

This is an electronic reprint of the original article.

This reprint may differ from the original in pagination and typographic detail.

Please cite the original version. 


\title{
Quantifying the spatial distribution and trends of supplementary feeding sites in South Africa and their potential contribution to vulture energetic requirements.
}

\author{
Christiaan W. Brink ${ }^{1}$, Andrea Santangeli ${ }^{1,2}$, Arjun Amar ${ }^{1}$, Kerri Wolter ${ }^{3}$, Gareth \\ Tate $^{4}$, Sonja Krüger ${ }^{5}$, Andrew S. Tucker ${ }^{6}$ and Robert L. Thomson ${ }^{1}$. \\ ${ }^{1}$ FitzPatrick Institute of African Ornithology, DST-NRF Centre of Excellence, University of Cape Town, \\ Cape Town, South Africa, ${ }^{2}$ The Helsinki Lab of Ornithology, Finnish Museum of Natural History, \\ University of Helsinki, Finland, ${ }^{3}$ VulPro, Rietfontein, South Africa, ${ }^{4}$ Birds of Prey Programme, \\ Endangered Wildlife Trust, Modderfontein, South Africa, ${ }^{5}$ Ezemvelo KwaZulu-Natal Wildlife, \\ Cascades, South Africa, ${ }^{6} \mathrm{CS}$ Vet, Pretoria, South Africa.
}

Corresponding author: Christiaan W. Brink

Address: John Day Zoology Building, University Avenue, Rondebosch Cape Town, South Africa.

Email: christiaanwillembrink@gmail.com

Short title: South African vulture supplementary feeding sites

Abstract

Old world vultures are the most threatened group of raptors globally. Supplementary feeding sites (SFS) are a popular conservation tool, widely used to assist vulture populations. Despite their popularity, the impact of SFS on vultures remains largely unstudied. A lack of knowledge on the number, distribution and management of SFS is a key factor hindering such research. In this study, we compile records of SFS in South Africa and conduct questionnaires with SFS managers to characterise SFS. We identify 143 currently active SFS. Our data suggest that SFS numbers have been stable over the last decade. The average provisioning rate for all SFS was $64.6 \mathrm{~kg} /$ day. Overall SFS provide an estimated 3301 tonnes of food to scavengers each year, the equivalent of $83 \%$ of the energetic needs of all vultures in the region. This contribution was highly skewed, however, with just $17 \%$ of active SFS sites providing $69 \%$ of all food. Furthermore, these resources were not equally distributed, with SFS in Limpopo, North West and Kwazulu-Natal provinces providing $83 \%$ of the total meat provisioned. The three most common meat types provided at SFS were beef (39\%), pork (33\%) and game (19\%). Worryingly, we found that $68 \%$ and $28 \%$ of SFS managers were unaware of 
the potential harmful effects of lead and veterinary drugs, respectively, which highlights potential poisoning risks associated with SFS. Examining exposure to SFS by different vulture species, we found that whilst SFS are accessible across the distribution range of vultures with large home ranges (e.g. African white-backed and Cape vultures), those species with smaller home ranges have relatively poor accessibility. With this study we demonstrate the potential importance, but also associated risks, of SFS to vultures in South Africa, and provide the information-base to assess the impacts of this popular but as yet largely un-assessed conservation tool.

Keywords: vulture restaurant, anthropogenic food, conservation management, scavengers.

\section{Introduction}

The decline of biodiversity often requires the implementation of intensive management actions (Butchart et al., 2010; Barnosky et al., 2011). Because of the inherent uncertainty in how biological systems will react to conservation interventions (Keith et al., 2011), some management actions can cause unintended negative effects on target species or ecosystems (Ainara Cortés-Avizanda et al., 2009; Wittmer, Elbroch, \& Marshall, 2013). Validating the beneficial outcome of such interventions is thus a crucial role of conservation science. To facilitate such inquiry, responsible management should entail continuous monitoring and assessment. This is the only way in which to ensure that limited conservation resources are not wasted on ineffective or detrimental interventions (Santangeli \& Sutherland, 2017).

Food supplementation is an intensive management intervention often meant to help threatened species. While its effects in a conservation context are in many cases unknown, unintended negative ecological effects of food supplementation have been reported (Robb et al., 2008; Milner et al., 2014). These include changes in social and movement behaviour (Duriez, Herman, \& Sarrazin, 2012; Jones et al., 2014; Fluhr et al., 2017), predation and selection pressures (Schmidt \& Hoi, 2002; Ainara Cortés-Avizanda et al., 2009), interspecific relationships (Carrete et al., 2010; Cortés-Avizanda et al., 2012) sex ratios and reproductive performance (Clout, Elliott, \& Robertson, 2002; Carrete, Donázar, \& Margalida, 2006) and various health factors (Blanco, Lemus, \& García-Montijano, 2011; Sorensen, van Beest, \& Brook, 2014).

Almost seventy percent of old-world vulture species are threatened with extinction (IUCN, 2019), the most rapid population declines occurring in the vulture-rich regions of Asia and Africa (Ogada et al., 2016). Over the last decade, the unnatural and accelerated mortality rates of vultures across Africa have led to the International Union for Conservation of Nature (IUCN) uplisting seven out of ten of the continent's vulture species to Critically Endangered and Endangered (Amar et al., 2018). While this can be attributed to various threats (Anderson, Maritz, \& Oosthuysen, 1999; Boshoff et al., 2011; McClure et al., 2018), the most prevalent of these is poisoning. This risk of poisoning include: direct poisoning - for traditional belief-based use of vulture parts (Mckean et al., 2013), or "sentinel poisoning", whereby poachers target vultures as they provide rangers with a clear sign of poaching 
events (Ogada et al., 2016), and indirect secondary poisoning - where vultures are the unintended victims of the poisoning of so-called problem carnivores (Santangeli et al., 2016). Similarly, vultures may be poisoned by feeding on livestock treated with veterinary drugs (Gilbert et al. 2002; Oaks et al. 2004), or lead contaminated carcasses (Bounas et al. 2016; Garbett et al. 2018), which may even lead to catastrophic population level impacts (Green et al., 2004).

The high mobility and wide ranging behaviours of vultures make conserving them challenging because conventional conservation measures, such as protected areas, may be insufficient (Santangeli et al., 2019). In South Africa, there has been a strong emphasis on providing additional food through supplementary feeding sites (SFS; often also referred to as "vulture restaurants", Cortés-Avizanda et al., 2016). These measures have been implemented because providing such food is typically assumed to reduce poisoning risk (Gilbert et al., 2007), with some evidence indicating it can also increase breeding success and survival (González et al., 2006; Oro et al., 2008). However, such effects are not ubiquitous and in some cases SFS show no effects (Krüger, Simmons, \& Amar, 2015; Oppel et al., 2016a). SFS therefore remain a debated conservation tool (Oppel et al., 2016b).

Anderson and colleagues (2005) previously estimated that there were around 140-145 active SFS in South Africa, with an annual increase of $9 \%$ per year. The majority of SFS are established informally by land managers, particularly as an easy and inexpensive form of carcass disposal (Mundy et al., 1992; Piper, 2004b). Therefore, many SFS are potentially operated without following best-practice guidelines (Piper, 2004a). Essential information on the number, status (active - providing food, or closed), location and provisioning rate of SFS is lacking and not collated into a systematic centralised database. This hinders investigations on the effects of SFS on vultures in Africa (e.g., Kane et al., 2014), which is essential to understand the conservation outcomes of SFS. The first step in quantifying the effectiveness of SFS is thus to systematically gather this information.

Here, we aim to fill this knowledge gap in South Africa and lay the basis for future studies on this common, yet un-assessed conservation tool. Specifically, we aim to i) determine the current and historical number and distribution of active SFS in South Africa; ii) quantify the amount and type of food resources being provisioned at these SFS; iii) estimate the contribution of SFS resources towards filling the energetic needs of the different vulture species based on their potential access to SFS.

\section{Methods}

\section{Ethics statement}

This study was approved by the Faculty of Science Research Ethics Committee at the University of Cape Town (Approval code: FSREC 83 - 2017). Participants provided informed verbal consent, as approved by the ethics committee. 


\section{Supplementary feeding site data}

We used existing datasets on SFS from three organisations in South Africa which are extensively involved in vulture conservation (VulPro, The Endangered Wildlife Trust and Ezemvelo KwaZulu-Natal Wildlife). These datasets were out-dated to various extents and the information they contained had not been verified during recent years. We consolidated all three databases.

We conducted a survey with the managers or affiliated persons of each SFS. The survey was conducted by a single interviewer (CWB) over the telephone or email, using an open-ended questionnaire (see Supplementary Material). Surveys were conducted between November 2017 and October 2018. Respondents were asked to provide a range of information regarding their SFS, most notably coordinates of the site, the status of the SFS (whether the site was active, i.e. provisioning food, or closed and no longer provisioning) their provisioning rates (tonnes per year), type of carcasses used, their date of establishment and closure and reasons for establishment and closure. SFS managers were also presented with a multiple-choice question regarding whether they believed that lead from spent ammunition or veterinary drugs present in carcasses could have any potential harmful effects on vultures.

\section{Provisioning rate calculations}

Respondents were asked to specify, as accurately as possible, the type and quantity of food (a combination of whole carcasses and offal) that they provide at their SFS within a given time unit. When respondents provided weights per carcass or specified the amount of offal in kilograms (the parts of an animal carcass that is discarded after butchering or dressing), these amounts were used. In cases where respondents provided a quantity range, the midpoint of this range was used to calculate provisioning rate. However, when livestock carcass weights were not provided but only the numbers of carcasses, we used the body mass of animals from the literature averaged across breeds within a specific livestock type (Cloete \& De Villiers, 1987; Cloete et al., 2000; Wells \& Krecek, 2001; Sheridan, Ferreira, \& Hoffman, 2003; Scholtz, 2010; Snyman, 2014a, 2014b, 2014c, 2014d, 2014e; Andrew Tucker unpubl. data).

To determine provisioning rate of game animals, the average mass of game species was derived from the 2016 South African hunting statistics (available from the Department of Environmental Affairs) and published weights (Stuart \& Stuart, 2015). When respondents indicated an amount provisioned during the hunting season, we assumed that this was provided over the average winter hunting season, which is three months in duration.

To calculate the amount of offal provided we used averaged dress out percentages (ratio of slaughtered and vicerated carcass to live weight) from the literature for each animal group. This was only needed for the game and pork category as all other livestock offal amounts were indicated in weights. South African dress out percentage for a range of ungulate species falls within a 52-61\% of body weight (Von La Chevallerie 1970; Hoffman 2000; Van Zyl \& Ferreira 2004; Hoffman \& Wiklund 2006; Hoffman et al. 2009; Swanepoel et 
al. 2016). Offal thus accounts for between $39-48 \%$ of live weight. We used the conservative measure of $40 \%$ of live weight for our calculations of offal weight as some offal is commonly used for human consumption. Dressing weights for domestic pigs were between $72-84 \%$ (Latorre et al. 2009; Warriss et al. 1990; Boler et al. 2012; Virgili et al. 2003), thus for pigs we used $20 \%$ as percentage offal of live weight. QGIS was used for all spatial analyses (QGIS, 2019).

\section{Calculation of vulture energetic needs}

To contextualise the total amount of food being provided by SFS, we calculated the total annual food requirements of all vultures in the South Africa, Lesotho and eSwantini region (Appendix 1). We used adult vulture population estimates, indications of the proportion of the population that are adults, and daily food requirements from the literature to do these calculations (Appendix 1). In addition to the SFS within South Africa, provisioning rates from two verified SFS in Lesotho and two in eSwatini were included in this calculation. The species evaluated included the IUCN Critically Endangered African white-backed vulture, Gyps africanus, Endangered Cape vulture, Gyps corprotheres, Endangered lappet-faced vulture, Torgos tracheliotos, Near Threatened bearded vulture, Gypaetus barbatus, Critically Endangered hooded vulture, Necrosyrtes monachus, and Critically Endangered whiteheaded vulture, Trigonoceps occipitalis (IUCN, 2019).

\section{Coverage of species range by SFS}

Adult vultures often have smaller home ranges than non-adults and thus their access to SFS is more restricted (eg. Krüger, Reid, \& Amar, 2014). For this reason, we focussed this analysis on adults only. We quantified the proportion of each species' distribution range that is accessible to SFS in the following way. First, we collated home range estimates for each species from the literature (Krüger, Reid, \& Amar, 2014; Kane et al., 2016; Garbett, 2018; Reading et al., 2019). Such estimates were unavailable for adult African white-backed vultures, but as evidence suggests they display similar movement behaviour as lappet-faced vultures (Spiegel, Getz, \& Nathan, 2013), we thus used lappet-faced vulture estimates as a proxy. The average across all species was used for white-headed vultures for which data were also unavailable. Assuming uniform circular home ranges, we converted these speciesspecific home range estimates to minimum and maximum buffers for each species. We used 95\% Kernel Density Estimates (KDE), 90\% in the case of bearded vultures, for the calculation of the maximum buffer radiuses and 50\% KDE for the minimum buffer radius of each species. . These species-specific radiuses were then used to create buffers around each active SFS in the region. Finally, we calculated the proportion of each vulture species' range covered by the minimum and maximum buffer surrounding SFS in the region. This yielded a minimum and maximum proportion of species range coverage by SFS. We repeated the above analyses using only SFS with high provisioning rates (>40 kg/day). 


\section{Results}

We were able to contact $92.4 \%$ of the SFS for which we had working contact details. The remainder either refrained from responding to all attempts at communication or had closed so long ago that no relevent respondent could be found. Of those we did contact, $72.4 \%$ participated in the study beyond just simple verrificaion of the status of their SFS. Among verified and currently active SFS, we had a response rate of $94.3 \%$.

\section{State of SFS in South Africa}

We verified the status of 232 SFS records in South Africa, including 25 new sites (i.e., not present in the three original datasets) that were mentioned by respondents and verified on an ad-hoc basis. Among verified SFS, 143 were active (Figure 1), and 89 were closed. Ninety entries remained unverified, due to out-dated contact information. Given the age of the databases and their entries, these were assumed to be closed.

\section{Trend and motivations of SFS establishment}

We gathered information on establishment and closure dates of 104 currently active and 39 closed SFS. The earliest reported establishment date was 1933. From 1975 numbers of active SFS increased sharply, but have remained relatively constant since around 2009 (Figure 3).

The main motivation for establishing an SFS was for conserving vultures (65\% of 159 total responses) and for the cleaning benefits vultures provide (26\%). Other reasons were the personal pleasure of running an SFS (12\%) and ecotourism (11\%).

Reasons for closing SFS were: managers moving away (22\% out of 55 responses), low vulture visitation rates (13\%), relocation of SFS $(11 \%)$, carcass contamination concerns and lack of control regarding dumping by general public (11\%), lack of carcasses for provisioning (7\%), and occurrence of powerline mortalities (7\%).

\section{Provisioning Rates}

We obtained information on provisioning rates from 132 of the 143 active SFS. Of these, 24 provided both livestock and game, 82 provided livestock only and 26 provided game only. Eight SFS that only provided game, indicated that their SFS was solely active during the hunting season. There was high variability in provisioning rate among SFS, with a mean \pm S.D. of $23.58 \mathrm{t} / \mathrm{y} \pm 38.84$ (range: $0.32-208.57 \mathrm{t} / \mathrm{y}$ ), equivalent to $64.61 \mathrm{~kg} / \mathrm{day} \pm 106.42$. Across all SFS for which data was collected, we estimated that 3113 tonnes of food are provided each year. If extrapolated across sites with unknown provisioning rates, using the average of similar types of sites in the same province (or across the entire country in the case of Nature and Game Reserves), then 3301 tonnes of food are provided across all known active SFS.

The contribution of food provisioned was highly skewed, with just $17 \%$ of active sites providing $69 \%$ of reported total annual provisioned food (Appendix 2). Sites with highest 
provisioning rates are generally affiliated with intensive livestock farms, abattoirs or NonGovernmental Organisations (NGO) who source carcasses from such operations. Sites that provided little food annually are represented more often by small-scale livestock farms. We report high variation in resource contribution by SFS across South Africa, with Limpopo, KwaZulu-Natal and North West provinces providing the majority of food resources (Figure 2). Across South Africa, most of the total food provisioned consisted of beef (39.2\%), pork $(33.3 \%)$ and game (19.4\%, Appendix 3). Less common meat sources included sheep (3.6\%), horses/donkeys (2.2\%), chicken (1.0\%) and goat (0.2\%).

\section{Potential energetic contribution of SFS}

We estimated that the extrapolated total provisioning rate of $3301 \mathrm{t} / \mathrm{y}$, plus $16 \mathrm{t} / \mathrm{y}$ provided at SFS in eSwatini and Lesotho, is enough to potentially fulfil about $83 \%$ of the annual food requirements for vultures in South Africa.

\section{Food safety}

Out of 111 respondents answering the question on the health risks posed to vultures from providing contaminated food, $32 \%$ of managers believed that lead from spent ammunition could be dangerous to vultures, $35 \%$ were not sure and $32 \%$ were convinced otherwise. For veterinary drugs, $72 \%$ believed that they could have harmful effects, $20 \%$ were unsure and $8 \%$ were convinced otherwise.

\section{Vulture range coverage by SFS}

The South African range of lappet-faced vultures, African white-backed vultures and Cape vultures had highest accessibility to SFS, with $100 \%$ of their range being covered by any SFS, and $79 \%$ to $81 \%$ when considering only SFS providing more than $40 \mathrm{~kg} / \mathrm{d}$ (Table 1). Conversely, hooded and bearded vultures had the lowest SFS range coverage (Table 1). 

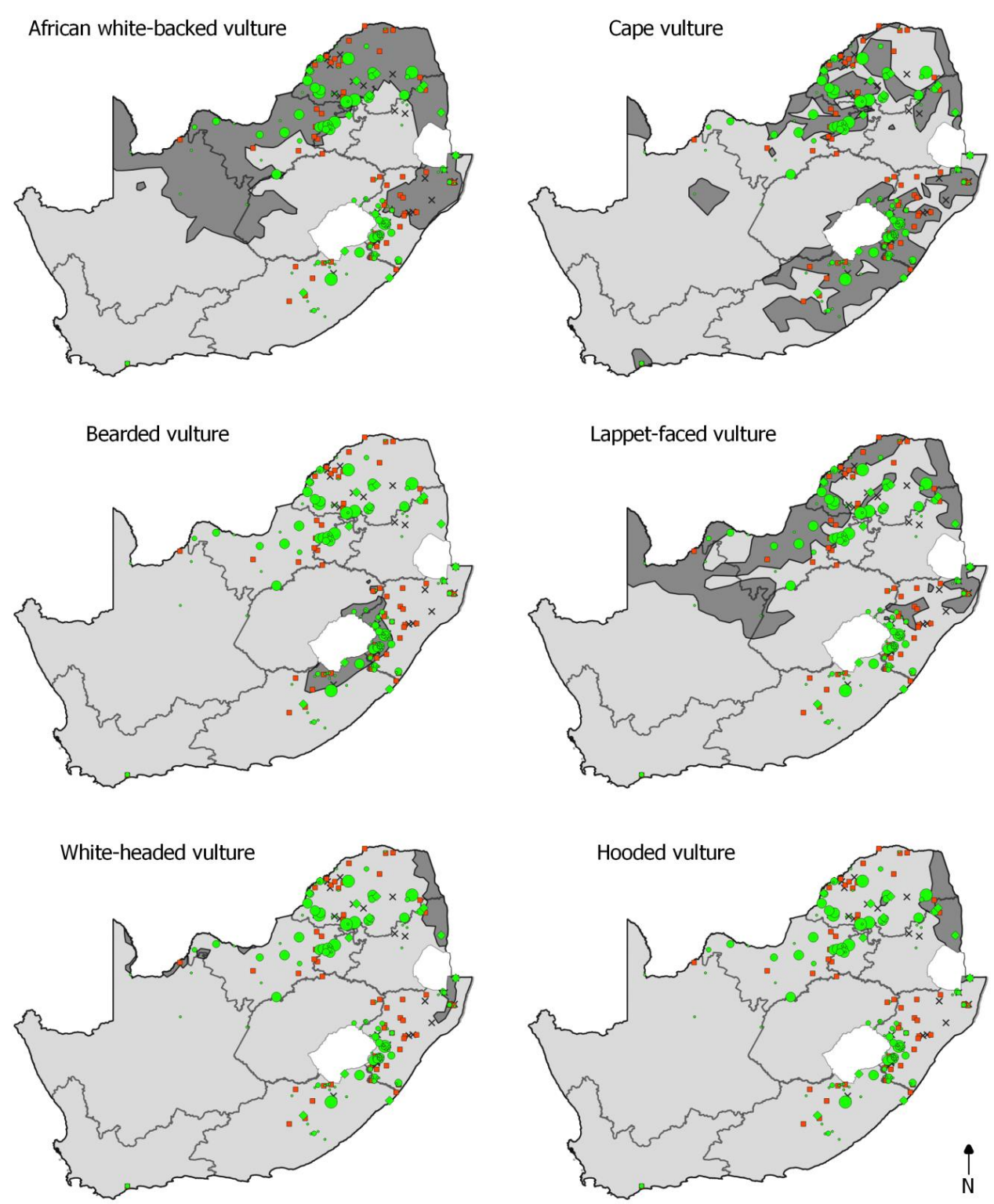

Legend

- Very High $(>300 \mathrm{~kg} / \mathrm{d})$ - Low $(20-40 \mathrm{~kg} / \mathrm{d})$

- High $(100-300 \mathrm{~kg} / \mathrm{d})$. Very Low $(<20 \mathrm{~kg} / \mathrm{d})$

- Medium (40-100 kg/d) * Unknown

- Closed

$\times \quad$ Not verified

$\square$ Vulture distribution

2 Figure 1: The distribution and status of vulture supplementary feeding sites in South Africa as verified by the present study. Active (green), closed (red) and unverified (black cross) supplementary feeding sites are indicated. The average daily food provisioning rate category of active sites is indicated by the size of the green circles, green diamonds indicate active

6 supplementary feeding but with unknown provisioning rates. The distribution of each of six 7 vulture species occurring in South Africa is shown in dark grey (data obtained from BirdLife 8 International and NatureServe 2015). 

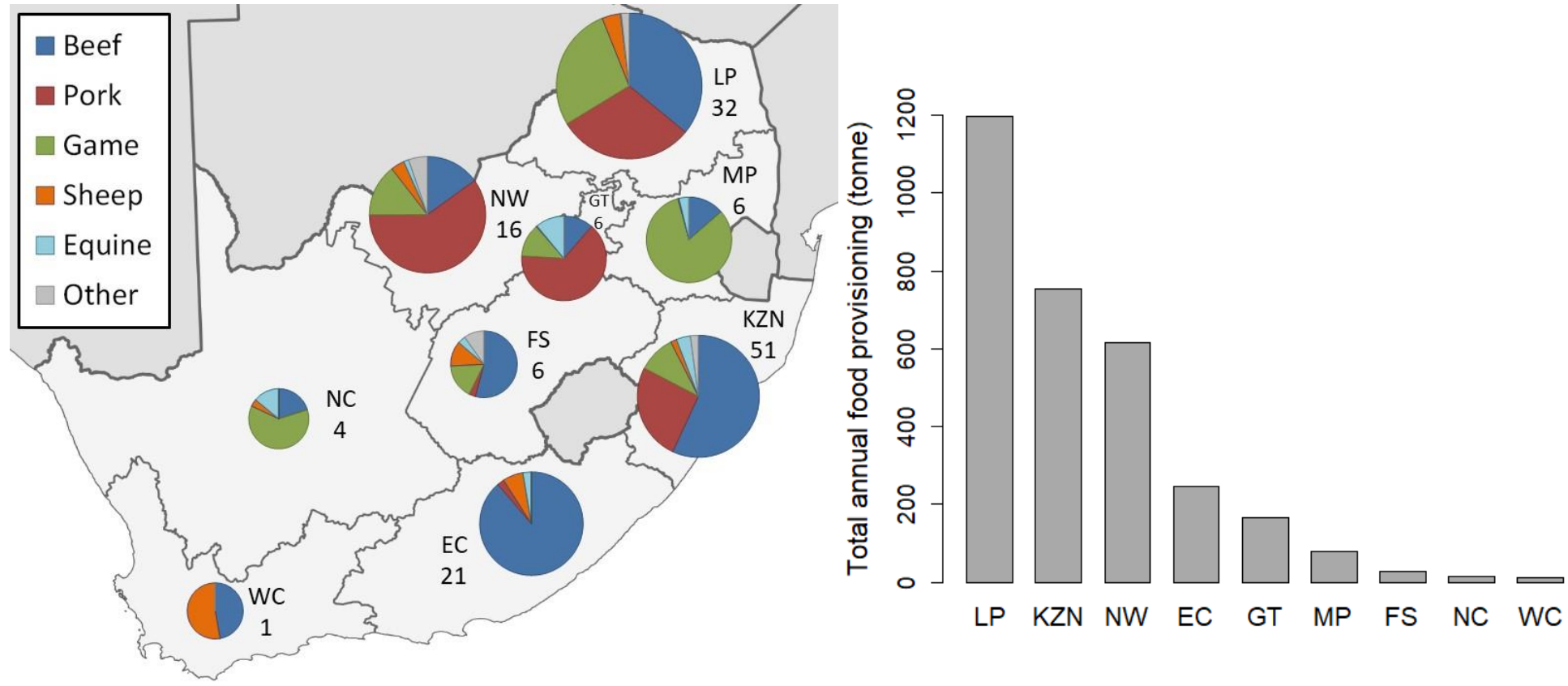

Figure 2: Proportional contribution of each meat type to the total food provisioned at supplementary feeding sites in each province in South Africa (shown by the pie charts within each region in the map). The size of each pie chart is proportional to the total amount of food provisioned in each province per year (log transformed to ease visualisation). Numbers below the name of each province in the map indicate the number of active supplementary feeding sites in that province. The total amount of food provided at supplementary feeding sites in each province in tonnes per year is reported in the histogram to the right. (LP = Limpopo, KZN $=$ KwaZulu Natal, NW $=$ North West, EC $=$ Eastern Cape, $\mathrm{GT}=$ Gauteng, MP = Mpumalanga, FS = Freestate, NC = Northern Cape, $\mathrm{WC}=$ Western Cape). 

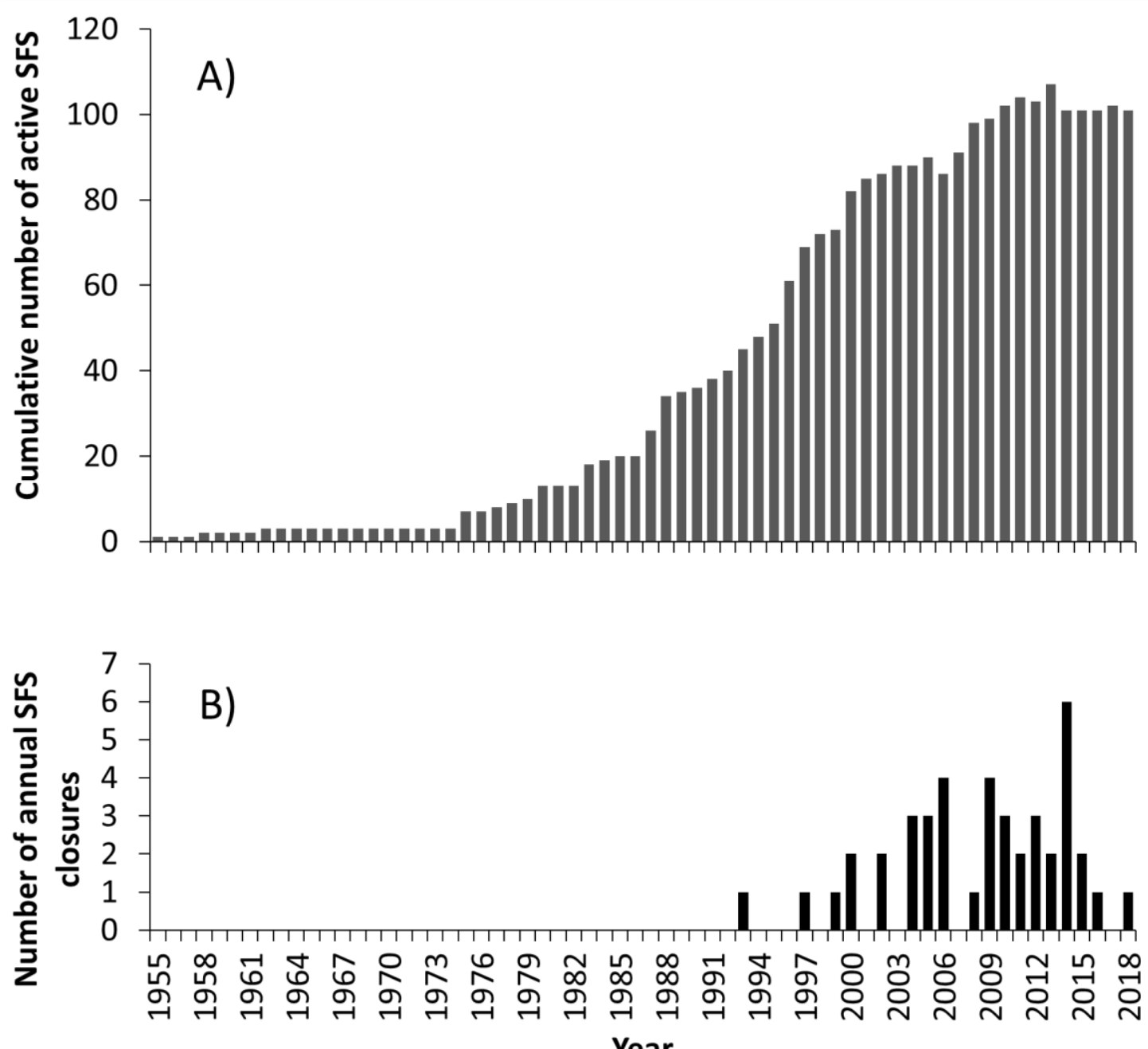
Year

20 Figure 3: A) Cumulative number of active SFS over time in South Africa, and B) the number 21 of annual SFS closures. This is based on information of opening and closing dates obtained 22 from 155 SFS. We start the timeline at 1955 for brevity, because between 1933 and 1955 23 only a single SFS was reported as active. Sites that did not provide this information were 24 excluded here. 
Table 1: The percentage area of vulture species' South African distribution range that is within adult vulture maximum (based on $95 \%$ Kernel Density Estimates, except for bearded vulture which is based on $90 \%$ Kernel Density Estimates) and minimum (based on 50\% Kernel Density Estimates) home range distances from SFS and SFS with higher provisioning rates respectively.

\begin{tabular}{|c|c|c|c|c|c|c|c|}
\hline \multirow[b]{2}{*}{ Species } & \multirow[b]{2}{*}{$\begin{array}{l}\text { Maximum } \\
\text { buffer } \\
\text { radius } \\
(\mathrm{km})\end{array}$} & \multirow[b]{2}{*}{$\begin{array}{l}\text { Minimum } \\
\text { buffer } \\
\text { radius } \\
(\mathrm{km})\end{array}$} & \multirow[b]{2}{*}{$\begin{array}{c}\text { South } \\
\text { African } \\
\text { distribution } \\
\text { range }\left(\mathrm{km}^{2}\right)\end{array}$} & \multicolumn{2}{|c|}{ All SFS } & \multicolumn{2}{|c|}{$\begin{array}{l}\text { Higher provisioning rate SFS } \\
\qquad(>40 \mathrm{~kg} / \mathrm{d})\end{array}$} \\
\hline & & & & $\begin{array}{l}\text { Percentage area } \\
\text { within maximum } \\
\text { home range } \\
\text { distance (\%) }\end{array}$ & $\begin{array}{l}\text { Percentage area } \\
\text { within minimum } \\
\text { home range } \\
\text { distance (\%) }\end{array}$ & $\begin{array}{c}\text { Percentage area } \\
\text { within maximum } \\
\text { home range } \\
\text { distance }(\%)\end{array}$ & $\begin{array}{c}\text { Percentage area } \\
\text { within minimum } \\
\text { home range } \\
\text { distance (\%) }\end{array}$ \\
\hline Lappet-faced vulture & 249 & 94 & 243927 & 100 & 84 & 79 & 45 \\
\hline African white-backed vulture & 249 & 94 & 399801 & 100 & 81 & 81 & 46 \\
\hline Cape vulture & 187 & 56 & 285533 & 100 & 72 & 80 & 41 \\
\hline White-headed vulture & 120 & 41 & 34717 & 92 & 41 & 56 & 5 \\
\hline Hooded vulture & 35 & 10 & 37888 & 33 & 5 & 14 & 2 \\
\hline Bearded vulture & 10 & 4 & 35898 & 24 & 6 & 7 & 2 \\
\hline
\end{tabular}




\section{Discussion}

Our study shows that use of SFS in South Africa is widespread, and they provide enough food to potentially fill almost all the energetic needs of the entire South African vulture population. Provisioned food was not distributed evenly, with some species having low access to SFS through their range. Therefore, vultures in the area are exposed to varying amounts of provisioned meat quantities and types, and the associated risks of provisioned food of which many SFS managers remain unaware. The numbers of active SFS have remained stable over the past decade.

\section{SFS trends}

The initial increase in SFS from the 1970s onwards can likely be ascribed to various awareness campaigns promoting the establishment of SFS to local landowners and the general public (Mundy et al. 1992). Combined with increased awareness of vulture declines, this may have accounted for the growing adoption of SFS by landowners. If the growth rate of SFS remained consistent since that of 2002, then today there would be 430 active SFS in South Africa (Anderson, Piper, \& Swan, 2005). Our results show a similar increase up to the year 2002, but a reduction in this rate afterwards, with SFS numbers plateauing in 2009.

\section{Adherence to best practices}

Livestock dominates the food provisioned by SFS in most areas. Due to widespread use of veterinary drugs in livestock production, many scavenger species may be exposed to these substances (Blanco et al., 2016; Blanco, Junza, \& Barrón, 2017) in a similar way as reported for Asian vultures (Shultz et al., 2004). Other veterinary drugs such as antibiotics may have unidentified long term sub-lethal effects that can influence the fitness of scavengers (Pitarch, Gil, \& Blanco, 2017). Game meat was provisioned at $34 \%$ of SFS and mostly originates from hunting activities. This provisioned meat may therefore contain lead fragments from spent lead ammunition. This is problematic as the harmful effects of lead on avian taxa are well documented (Haig et al., 2014). Lead is known to accumulate in vultures in southern Africa and a worrying amount of individuals display lead levels consistent with subclinical to severe clinical effects (Garbett et al., 2018; Krüger \& Amar, 2018; van den Heever et al., 2019). Ingestion of lead fragments in carcasses have been indicated as the most likely cause of these elevated lead levels as these elevated levels were not found in non-scavenging species and were also associated with hunting season and areas (Garbett et al., 2018; van den Heever et al., 2019).

The safety of the food provided at SFS depends on how aware managers are of threats, and how seriously they take them. In South Africa, our survey suggested that $28 \%$ of SFS managers were unaware of potential harmful effects of veterinary drugs and $68 \%$ were unaware of the harmful effects of lead. Consequently, carcasses provided at many SFS could be contaminated with these harmful substances, which could have a negative impact on the vultures that consume them. Another indication that best practice is not always followed is 
illustrated by the small percentage of SFS that are providing poultry carcasses, potentially exposing vultures to avian influenza (Ducatez et al., 2007). Some respondents also reported powerline associated mortalities at their sites which represents a main contributing factor for the closure of $7 \%$ of SFS. This indicates that some SFS may potentially increase the collision and electrocution risks to vultures. We suggest that conservation practitioners should work more in connection with SFS managers in order to increase their awareness of these unintended consequences and reduce their likelihood through promoting best management practices. In cases where negligent management practices are resulting in mortalities of endangered species, the relevant authorities should intervene.

\section{Temporal variation in SFS provisioning: a paradox}

Our updated information on distribution and food provision of SFS in South Africa will allow in-depth analyses of how SFS may influence space use of vultures. Vultures have historically evolved to use temporally variable and unpredictable food resources (Monsarrat et al., 2013). Conversely, regular feeding at SFS associated with intensive livestock farming operations, could lead to the development of routine behaviours and dependence (Fluhr et al., 2017). Within an African context, limited information exists on this potential impact of SFS on vulture behavior. Anecdotal knowledge in Southern Africa suggests this may be species-specific. For example, dependence on SFS seems low for the Cape vulture (Kane et al., 2016), but high for non-adult bearded vultures (Reid et al., 2015).

Paradoxically, while foraging naturally, vultures may have an increased risk to come into contact with carcasses that have been laced with poison (Monadjem et al., 2018). Regular and copious provisioning of safe food at SFS could thus lead to a reduction in poisoning risk. Initially, SFS were only viewed as a temporary means to 'buy time' for addressing the ultimate threats that are causing vulture declines. Unfortunately, after 40 years since the introduction of SFS, the threat of poisoning is still high, and SFS have become an established tool for general application.

\section{Expansion of the SFS network}

Many conservation organisations promote the establishment of SFS (Birds of Prey Programme, 2007). They do so based on different unverified assumptions e.g. that SFS reduces localized poisoning risk, that SFS can divert vultures from areas of high risk and that in the absence of SFS, vulture populations experience food shortages. In order for the expansion of the existing SFS network to be evidence-based, such assumptions first need verification through scientific investigation. Once evidence for a measurable net positive impact on vulture demographic parameters has been obtained, then this tool can be considered on a case-by-case basis. Given the current lack of such evidence, decisions on SFS establishment are made in the dark (Cook, Hockings, \& Carter, 2010).

\section{Future research}


Parts of the SFS database were already being used in research prior to this study and thus prior to our verification (e.g., Krüger, Simmons, \& Amar, 2015; Kane et al., 2016). A visual comparison of the results of this study and the locations used by Kane et al. (2016) suggests that roughly $22 \%$ of the 110 SFS included in their study were miscategorised. Their study also omitted at least 70 active SFS. One of the aims of the present study is therefore to provide up to date information that can assist future analyses exploring the influence of SFS on vulture behaviour or demographics.

Future studies need to verify the basic assumptions on the demographic effects of SFS on vulture populations. In addition, research should focus on quantifying the role of SFS in reducing poisoning risk to vultures, e.g. by studying impacts on ranging behaviours. For example, it may be that SFS could be strategically located to divert vulture movements away from areas with a high threat of poisoning or wind turbine collision (Reid et al., 2015). Finally, the effects of different feeding methods (regular vs. irregular feeding, whole carcasses versus small food parcels) on the above factors and the structure and functioning of the South African scavenger guild could be assessed. In Europe, increased predictability of resources at SFS favoured more dominant species to the detriment of less competitive and often more threatened vulture species (Cortés-Avizanda et al., 2012). Feeding methods could thus play an important role when SFS are aimed at supporting a particular species in a particular area.

Although we hope this study can assist in future research, SFS security is a concern.

\section{Conclusion}

To assess the effectiveness of conservation interventions, it is crucial to know where, when and how such interventions are implemented. A lack of this information prevents such assessments, ultimately leading to a potential waste of scarce conservation resources that, in the case of vulture SFS, may even have counterproductive effects. In this study, we provide the necessary information to enable such research and provide conservation managers with an updated view of the South African SFS network.

\section{Acknowledgements}

We would like to thank all respondents for taking the time to participate, as well as Jordan-Laine Calder for her contribution in the early phases of this project. This study was funded by the NRF-DST Centre of Excellence funding to the FitzPatrick Institute of Ornithology. AS was funded by the Academy of Finland (grant n. 307909). VulPro would like to thank all their sponsors who contributed to the data collection of this study namely; Cheyenne Mountain Zoo, Cleveland Metroparks Zoo and Cleveland Zoological Society, Columbus Zoo, Colchester Zoo, Hans Hoheisen Charitable Trust, Riverbanks Zoo \& Garden, The Tusk Trust, Zoo Atlanta - Reeder Conservation Fund and 3M. 


\section{References}

Amar, A., Buij, R., Suri, J., Sumasgutner, P., \& Virani, M. Z. (2018). Conservation and ecology of African Raptors. In Birds Prey Biol. Conserv. XXI century. pp. 419-455. Cham: Springer International Publishing.

Anderson, M. D., Maritz, A. W. A., \& Oosthuysen, E. (1999). Raptors drowning in farm reservoirs in South Africa. Ostrich 70, 139-144.

Anderson, M. D., Piper, S. E., \& Swan, G. E. (2005). Non-steroidal anti-inflammatory drug use in South Africa and possible effects on vultures. S. Afr. J. Sci. 101, 112-114.

Barnosky, A. D., Matzke, N., Tomiya, S., Wogan, G. O. U., Swartz, B., Quental, T. B., Marshall, C., McGuire, J. L., Lindsey, E. L., Maguire, K. C., Mersey, B., \& Ferrer, E. a. (2011). Has the Earth's sixth mass extinction already arrived? Nature 471, 51-57.

Birds of Prey Programme. (2007). The Sasol guide to the establishment and operation of supplementary feeding sites for vultures. Modderfontein, South Africa: The Endangered Wildlife Trust.

Blanco, G., Junza, A., \& Barrón, D. (2017). Occurrence of veterinary pharmaceuticals in golden eagle nestlings: Unnoticed scavenging on livestock carcasses and other potential exposure routes. Sci. Total Environ. 586, 355-361.

Blanco, G., Junza, A., Segarra, D., Barbosa, J., \& Barrón, D. (2016). Wildlife contamination with fluoroquinolones from livestock: Widespread occurrence of enrofloxacin and marbofloxacin in vultures. Chemosphere 144, 1536-1543.

Blanco, G., Lemus, J. A., \& García-Montijano, M. (2011). When conservation management becomes contraindicated: impact of food supplementation on health of endangered wildlife. Ecol. Appl. 21, 2469-2477.

Boler, D. D., Killefer, J., Meeuwse, D. M., King, V. L., McKeith, F. K., \& Dilger, A. C. (2012). Effects of slaughter time post-second injection on carcass cutting yields and bacon characteristics of immunologically castrated male pigs. J. Anim. Sci. 90, 334-344.

Boshoff, A. F., Minnie, J. C., Tambling, C. J., \& Michael, M. D. (2011). The impact of power linerelated mortality on the Cape Vulture Gyps coprotheres in a part of its range, with an emphasis on electrocution. Bird Conserv. Int. 21, 311-327.

Bounas, A., Ganoti, M., \& Giannakaki, E. (2016). First confirmed case of lead poisoning in the endangered Egyptian Vulture (Neophron percnopterus) in the Balkans. Vulture News 70, 22-29.

Butchart, S. H. M., Walpole, M., Collen, B., van Strien, a., Scharlemann, J. P. W., Almond, R. E. a., Baillie, J. E. M., Bomhard, B., Brown, C., Bruno, J., Carpenter, K. E., Carr, G. M., Chanson, J., Chenery, a. M., Csirke, J., Davidson, N. C., Dentener, F., Foster, M., Galli, a., Galloway, J. N., Genovesi, P., Gregory, R. D., Hockings, M., Kapos, V., Lamarque, J.-F., Leverington, F., Loh, J., McGeoch, M. a., McRae, L., Minasyan, a., Morcillo, M. H., Oldfield, T. E. E., Pauly, D., Quader, 

S., Revenga, C., Sauer, J. R., Skolnik, B., Spear, D., Stanwell-Smith, D., Stuart, S. N., Symes, a., Tierney, M., Tyrrell, T. D., Vie, J.-C., \& Watson, R. (2010). Global Biodiversity: Indicators of Recent Declines. Science (80-. ). 328, 1164-1168.

Carrete, M., Donázar, J. A., \& Margalida, A. (2006). Density-dependent productivity depression in Pyrenean Bearded Vultures: Implications for conservation. Ecol. Appl. 16, 1674-1682.

Carrete, M., Lambertucci, S. A., Speziale, K., Ceballos, O., Travaini, A., Delibes, M., Hiraldo, F., \& Donázar, J. A. (2010). Winners and losers in human-made habitats: Interspecific competition outcomes in two Neotropical vultures. Anim. Conserv. 13, 390-398.

Cloete, S. W. P., \& De Villiers, T. T. (1987). Production parameters for a commercial Dorper flock on extensive pasture. S. Afr. J. Anim. Sci. 17, 121-127.

Cloete, S. W. P., Snyman, M. A., \& Herselman, M. J. (2000). Productive performance of Dorper sheep. Small Rumin. Res. 36, 119-135.

Clout, M. N., Elliott, G. P., \& Robertson, B. C. (2002). Effects of supplementary feeding on the offspring sex ratio of kakapo: a dilemma for the conservation of a polygynous parrot. Biol. Conserv. 107, 13-18.

Cook, C. N., Hockings, M., \& Carter, R. W. (2010). Conservation in the dark? The information used to support management decisions. Front. Ecol. Environ. 8, 181-188.

Cortés-Avizanda, A., Jovani, R., Carrete, M., \& Donázar, J. A. (2012). Resource unpredictability promotes species diversity and coexistence in an avian scavenger guild: A field experiment. Ecology 93, 2570-2579.

Cortés-Avizanda, Ainara, Blanco, G., Devault, T. L., Markandya, A., Virani, M. Z., Brandt, J., \& Donázar, J. A. (2016). Supplementary feeding and endangered avian scavengers: Benefits, caveats, and controversies. Front. Ecol. Environ. 14, 191-199.

Cortés-Avizanda, Ainara, Carrete, M., Serrano, D., \& Donázar, J. A. (2009). Carcasses increase the probability of predation of ground-nesting birds: A caveat regarding the conservation value of vulture restaurants. Anim. Conserv. 12, 85-88.

Ducatez, M. F., Tarnagda, Z., Tahita, M. C., Sow, A., de Landtsheer, S., Londt, B. Z., Brown, I. H., Osterhaus, D. M. E., Fouchier, R. A. M., Ouedraogo, J.-B. B., \& Muller, C. P. (2007). Genetic characterization of HPAI (H5N1) viruses from poultry and wild vultures, Burkina Faso. Emerg. Infect. Dis. 13, 611-3.

Duriez, O., Herman, S., \& Sarrazin, F. (2012). Intra-specific competition in foraging Griffon Vultures Gyps fulvus : 2. The influence of supplementary feeding management. Bird Study 59, 193-206.

Fluhr, J., Benhamou, S., Riotte-Lambert, L., \& Duriez, O. (2017). Assessing the risk for an obligate scavenger to be dependent on predictable feeding sources. Biol. Conserv. 215, 92-98.

Garbett, R. A. (2018). Conservation of raptors and vultures in Botswana: with a focus on lappet-faced vultures Torgos tracheliotos. Thesis. 
Garbett, R., Maude, G., Hancock, P., Kenny, D., Reading, R., \& Amar, A. (2018). Association between hunting and elevated blood lead levels in the critically endangered African white-backed vulture Gyps africanus. Sci. Total Environ. 630, 1654-1665.

Gilbert, M., Virani, M. Z., Watson, R. T., Oaks, J. L., Benson, P. C., Khan, A. A., Ahmed, S., Chaudhry, J., Arshad, M., Mahmood, S., \& Ali Shah, Q. (2002). Breeding and mortality of Oriental Whitebacked Vulture Gyps bengalensis in Punjab Province, Pakistan. Bird Conserv. Int. 12, 311-326.

Gilbert, M., Watson, R. T., Ahmed, S., Asim, M., \& Johnson, J. A. (2007). Vulture restaurants and their role in reducing diclofenac exposure in Asian vultures. Bird Conserv. Int. 17, 63-77.

González, L. M., Margalida, A., Sánchez, R., \& Oria, J. (2006). Supplementary feeding as an effective tool for improving breeding success in the Spanish imperial eagle (Aquila adalberti). Biol. Conserv. 129, 477-486.

Green, R. E., Newton, I., Shultz, S., Cunningham, A. A., Gilbert, M., Pain, D. J., \& Prakash, V. (2004). Diclofenac poisoning as a cause of vulture population declines across the Indian subcontinent. J. Appl. Ecol. 41, 793-800.

Haig, S. M., D’Elia, J., Eagles-Smith, C., Fair, J. M., Gervais, J., Herring, G., Rivers, J. W., \& Schulz, J. H. (2014). The persistent problem of lead poisoning in birds from ammunition and fishing tackle. Condor 116, 408-428.

Hoffman, L. C., Mostert, A. C., Kidd, M., \& Laubscher, L. L. (2009). Meat quality of kudu (Tragelaphus strepsiceros) and impala (Aepyceros melampus): Carcass yield, physical quality and chemical composition of kudu and impala Longissimus dorsi muscle as affected by gender and age. Meat Sci. 83, 788-795.

Hoffman, L. C., \& Wiklund, E. (2006). Game and venison - meat for the modern consumer. Meat Sci. 74, 197-208.

Hoffman, Louwrens C. (2000). The yield and carcass chemical composition of impala (Aepyceros melampus), a southern African antelope species. J. Sci. Food Agric. 80, 752-756.

Isomursu, M., Koivusaari, J., Stjernberg, T., Hirvelä-Koski, V., \& Venäläinen, E.-R. (2018). Lead poisoning and other human-related factors cause significant mortality in white-tailed eagles. Ambio 47, 858-868.

IUCN. (2019). The IUCN Red List of Thretened Species. Version 2019-2.

Jones, J. D., Kauffman, M. J., Monteith, K. L., Scurlock, B. M., Albeke, S. E., \& Cross, P. C. (2014). Supplemental feeding alters migration of a temperate ungulate. Ecol. Appl. 24, 1769-1779.

Kane, A., Jackson, A. L., Monadjem, A., Colomer, M. A., \& Margalida, A. (2014). Carrion ecology modelling for vulture conservation: Are vulture restaurants needed to sustain the densest breeding population of the African white-backed vulture? Anim. Conserv. 18, 279-286.

Kane, A., Wolter, K., Neser, W., Kotze, A., Naidoo, V., \& Monadjem, A. (2016). Home range and habitat selection of Cape Vultures Gyps coprotheres in relation to supplementary feeding. Bird 
Keith, D. A., Martin, T. G., McDonald-Madden, E., \& Walters, C. (2011). Uncertainty and adaptive management for biodiversity conservation. Biol. Conserv. 144, 1175-1178.

Krüger, S., Reid, T., \& Amar, A. (2014). Differential Range Use between Age Classes of Southern African Bearded Vultures Gypaetus barbatus. PLoS One 9, e114920.

Krüger, Sonja C., \& Amar, A. (2018). Lead exposure in the Critically Endangered Bearded Vulture (Gypaetus barbatus) population in southern Africa. J. Raptor Res. 52, 1-10.

Krüger, Sonja Carin, Simmons, R., \& Amar, A. (2015). Anthropogenic activities influence the abandonment of Bearded Vulture Gypaetus barbatus territories in southern Africa. Condor Ornithol. Appl. 117, 94-107.

Latorre, M. A., Ripoll, G., García-Belenguer, E., \& Ariño, L. (2009). The increase of slaughter weight in gilts as a strategy to optimize the production of Spanish high quality dry-cured ham1. J. Anim. Sci. 87, 1464-1471.

McClure, C. J. W., Westrip, J. R. S., Johnson, J. A., Schulwitz, S. E., Virani, M. Z., Davies, R., Symes, A., Wheatley, H., Thorstrom, R., Amar, A., Buij, R., Jones, V. R., Williams, N. P., Buechley, E. R., \& Butchart, S. H. M. (2018). State of the world's raptors: Distributions, threats, and conservation recommendations. Biol. Conserv.

Mckean, S., Mander, M., Diederichs, N., Ntuli, L., Mavundla, K., Williams, V., \& Wakelin, J. (2013). The impact of traditional use on vultures in South Africa. Vulture News 65, 15-36.

Milner, J. M., Van Beest, F. M., Schmidt, K. T., Brook, R. K., \& Storaas, T. (2014). To feed or not to feed? Evidence of the intended and unintended effects of feeding wild ungulates. J. Wildl. Manage. 78, 1322-1334.

Monadjem, A., Kane, A., Botha, A., Kelly, C., \& Murn, C. (2018). Spatially explicit poisoning risk affects survival rates of an obligate scavenger. Sci. Rep. 8, 4364.

Monsarrat, S., Benhamou, S., Sarrazin, F., Bessa-Gomes, C., Bouten, W., \& Duriez, O. (2013). How Predictability of Feeding Patches Affects Home Range and Foraging Habitat Selection in Avian Social Scavengers? PLoS One 8, 1-11.

Mundy, P., Butchart, D., Ledger, J., \& Piper, S. (1992). The Vultures of Africa. London: Academic Press.

Oaks, J. L., Gilbert, M., Virani, M. Z., Watson, R. T., Meteyer, C. U., Rideout, B. A., Shivaprasad, H. L., Ahmed, S., Iqbal Chaudhry, M. J., Arshad, M., Mahmood, S., Ali, A., \& Ahmed Khan, A. (2004). Diclofenac residues as the cause of vulture population decline in Pakistan. Nature 427, 630633.

Ogada, D., Shaw, P., Beyers, R. L., Buij, R., Murn, C., Thiollay, J. M., Beale, C. M., Holdo, R. M., Pomeroy, D., Baker, N., Krüger, S. C., Botha, A., Virani, M. Z., Monadjem, A., \& Sinclair, A. R. E. (2016). Another Continental Vulture Crisis: Africa's Vultures Collapsing toward Extinction. 
Oppel, S., Dobrev, V., Arkumarev, V., Saravia, V., Bounas, A., Kret, E., Skartsi, T., Velevski, M., Stoychev, S., \& Nikolov, S. C. (2016a). Assessing the effectiveness of intensive conservation actions: Does guarding and feeding increase productivity and survival of Egyptian Vultures in the Balkans? Biol. Conserv. 198, 157-164.

Oppel, S., Dobrev, V., Arkumarev, V., Saravia, V., Bounas, A., Kret, E., Skartsi, T., Velevski, M., Stoychev, S., \& Nikolov, S. C. (2016b). Should we trust beliefs or data when assessing conservation interventions? A reply to Stoynov 2016. Biol. Conserv. 204, 149-150.

Oro, D., Margalida, A., Carrete, M., Heredia, R., \& Donázar, J. A. (2008). Testing the goodness of supplementary feeding to enhance population viability in an endangered vulture. PLoS One $\mathbf{3}$, e4084.

Piper, S. E. (2004a). Vulture Restaurants-Conflict in the midst of Plenty. In R. . Chancellor \& B.-U. Meyburg (Eds.), Proc. 6th World Conf. Birds Prey Owls. pp. 341-349. Budapest: WWGBP and MME.

Piper, S. E. (2004b). Vulture Restaurants. In A. F. Monadjem, A., Anderson, M.D., Piper, S.E. \& Boshoff (Ed.), Vultures South. Africa - Quo Vadis?. Proc. a Work. vulture Res. Conserv. South. Africa. pp. 220-227. Johannesburg: Birds of Prey Working Group.

Pitarch, A., Gil, C., \& Blanco, G. (2017). Oral mycoses in avian scavengers exposed to antibiotics from livestock farming. Sci. Total Environ. 605-606, 139-146.

Prakash, V., Pain, D. J., Cunningham, A. A., Donald, P. F., Prakash, N., Verma, A., Gargi, R., Sivakumar, S., \& Rahmani, A. R. (2003). Catastrophic collapse of Indian white-backed Gyps bengalensis and long-billed Gyps indicus vulture populations. Biol. Conserv. 109, 381-390.

QGIS. (2019). QGIS Geographic Information System. Open Source Geospatial Foundation Project.

Reading, R. P., Bradley, J., Hancock, P., Garbett, R., Selebatso, M., \& Maude, G. (2019). Home-range size and movement patterns of Hooded Vultures Necrosyrtes monachus in southern Africa. Ostrich 90, 73-77.

Reid, T., Kruger, S., Whitfield, P. D., \& Amar, A. (2015). Using Spatial analysis of bearded vulture movement in southern Africa to inform wind turbine placement. J. Appl. Ecol. 881-892.

Robb, G. N., McDonald, R. A., Chamberlain, D. E., \& Bearhop, S. (2008). Food for thought: Supplementary feeding as a driver of ecological change in avian populations. Front. Ecol. Environ. 6, 476-484.

Santangeli, A., Arkumarev, V., Rust, N., \& Girardello, M. (2016). Understanding, quantifying and mapping the use of poison by commercial farmers in Namibia - Implications for scavengers' conservation and ecosystem health. Biol. Conserv. 204, 205-211.

Santangeli, A., Girardello, M., Buechley, E., Botha, A., Minin, E. Di, \& Moilanen, A. (2019). Priority areas for conservation of Old World vultures. Conserv. Biol. 33, 1056-1065. 
Santangeli, A., \& Sutherland, W. J. (2017). The Financial Return from Measuring Impact. Conserv. Lett. 10, 354-360.

Schmidt, K. T., \& Hoi, H. (2002). Supplemental feeding reduces natural selection in juvenile red deer. Ecography (Cop.). 25, 265-272.

Scholtz, M. M. (2010). Beef Breeding in South Africa. 2nd ed. Pretoria: Agticultural Research Council. Sheridan, R., Ferreira, A. ., \& Hoffman, L. . (2003). Production efficiency of South African Mutton Merino lambs and Boer goat kids receiving either a low or a high energy feedlot diet. Small Rumin. Res. 50, 75-82.

Shultz, S., Baral, H. S., Charman, S., Cunningham, A. A., Das, D., Ghalsasi, G. R., Goudar, M. S., Green, R. E., Jones, A., Nighot, P., Pain, D. J., \& Prakash, V. (2004). Diclofenac poisoning is widespread in declining vulture populations across the Indian subcontinent. Proc. R. Soc. B Biol. Sci. 271, S458-S460.

Snyman, M. A. (2014a). South African sheep breeds: Dohne Merino sheep. Grootfontein Agricultural Development Institute, Middelburg.

Snyman, M. A. (2014b). South African sheep breeds: Merino sheep. Grootfontein Agricultural Development Institute, Middelburg.

Snyman, M. A. (2014c). South African sheep breeds: SA Mutton Merino sheep. Grootfontein Agricultural Development Institute, Middelburg.

Snyman, M. A. (2014d). South African sheep breeds: Dorper sheep. Grootfontein Agricultural Development Institute, Middelburg.

Snyman, M. A. (2014e). South African sheep breeds: Dormer sheep. Grootfontein Agricultural Development Institute, Middelburg.

Sorensen, A., van Beest, F. M., \& Brook, R. K. (2014). Impacts of wildlife baiting and supplemental feeding on infectious disease transmission risk: A synthesis of knowledge. Prev. Vet. Med. 113, 356-363.

Spiegel, O., Getz, W. M., \& Nathan, R. (2013). Factors Influencing Foraging Search Efficiency: Why Do Scarce Lappet-Faced Vultures Outperform Ubiquitous White-Backed Vultures? Am. Nat. 181, E102-E115.

Stuart, C., \& Stuart, M. (2015). Stuart's field guide to mammals of southern Africa: Including Angola, Zambia and Malawi. Cape Town, South Africa: Struik Publishers.

Swanepoel, M., Leslie, A. J., Van der Rijst, M., \& Hoffman, L. C. (2016). Physical and chemical characteristics of warthog (Phacochoerus africanus) meat. African J. Wildl. Res. 46, 103-120.

van den Heever, L., Smit-Robinson, H., Naidoo, V., \& McKechnie, A. E. (2019). Blood and bone lead levels in South Africa's Gyps vultures: Risk to nest-bound chicks and comparison with other avian taxa. Sci. Total Environ. 669, 471-480. 
Van Zyl, L., \& Ferreira, A. V. (2004). Physical and chemical carcass composition of springbok (Antidorcas marsupialis), blesbok (Damaliscus dorcas phillipsi) and impala (Aepyceros melampus). Small Rumin. Res. 53, 103-109.

Virgili, R., Degni, M., Schivazappa, C., Faeti, V., Poletti, E., Marchetto, G., Pacchioli, M. T., \& Mordenti, A. (2003). Effect of age at slaughter on carcass traits and meat quality of Italian heavy pigs1. J. Anim. Sci. 81, 2448-2456.

Von La Chevallerie, M. (1970). Meat production from wild ungulates. Proc. South African Soc. Anim. prod. 9, 73-87.

Warriss, P. D., Brown, S. N., Rolph, T. P., \& Kestin, S. C. (1990). Interactions between the betaadrenergic agonist salbutamol and genotype on meat quality in pigs. J. Anim. Sci. 68, 3669.

Wells, D., \& Krecek, R. C. (2001). Socioeconomic, health and management aspects of working donkeys in Moretele 1, North West Province, South Africa. J. South African Vet. Assoc. Van Die Suid-Afrikaanse Veterinere Ver. 72, 37-43.

Wittmer, H. U., Elbroch, L. M., \& Marshall, A. J. (2013). Good intentions gone wrong: Did conservation management threaten Endangered huemul deer Hippocamelus bisulcus in the future Patagonia National Park? Oryx 47, 393-402. 


\section{$388 \quad$ Appendix}

389 Appendix 1: South African population size and total annual food requirement estimates for six vulture species.

\begin{tabular}{|c|c|c|c|c|c|c|c|}
\hline Common name & Scientific name & $\begin{array}{c}\text { Number of } \\
\text { adult vultures }\end{array}$ & $\begin{array}{l}\text { Proportion } \\
\text { adults }\end{array}$ & $\begin{array}{l}\text { Population } \\
\text { estimate }\end{array}$ & $\begin{array}{l}\text { Daily food } \\
\text { requirements } \\
\text { (kg) }\end{array}$ & $\begin{array}{l}\text { Annual food } \\
\text { requirement } \\
\text { (t) }\end{array}$ & $\begin{array}{c}\text { Annual } \\
\text { provisioning } \\
\text { in species } \\
\text { distribution } \\
\text { (t/y) }\end{array}$ \\
\hline African white-backed vulture & Gyps africanus & $7350^{a}$ & $0.67^{b}$ & 10970 & $0.4^{c}$ & 1601.6 & 2218.0 \\
\hline Cape vulture & Gyps corprotheres & $8800^{a}$ & $0.75^{d}$ & 11733 & $0.52^{c}$ & 2227.0 & 2448.9 \\
\hline White-headed vulture & Trigonoceps occipitalsis & $158^{\mathrm{a}}$ & $0.75^{\mathrm{e}}$ & 211 & $0.35^{c}$ & 27.0 & 84.6 \\
\hline Lappet-faced vulture & Torgos tracheliotos & $338^{a}$ & $0.81^{\mathrm{e}}$ & 417 & $0.5^{c}$ & 76.1 & 1190.0 \\
\hline Hooded vulture & Necrosyrtes monachus & $150^{a}$ & $0.65^{f}$ & 231 & $0.35^{c}$ & 29.5 & 120.1 \\
\hline Bearded vulture & Gypaetus barbatus & $233^{a}$ & $0.6^{f}$ & 388 & $0.3^{g}$ & 42.5 & 737.4 \\
\hline TOTAL & & 17029 & & 23950 & & 4003.6 & \\
\hline
\end{tabular}

390 a Taylor et al. 2015, ' Murn and Botha 2018, cMundy et al. 1992, dRobertson 1984, e'Kemp and Begg 2001, , ${ }^{\mathrm{C} B r o w n} 1997,{ }^{\mathrm{D} D o n}$ azar 1993. 


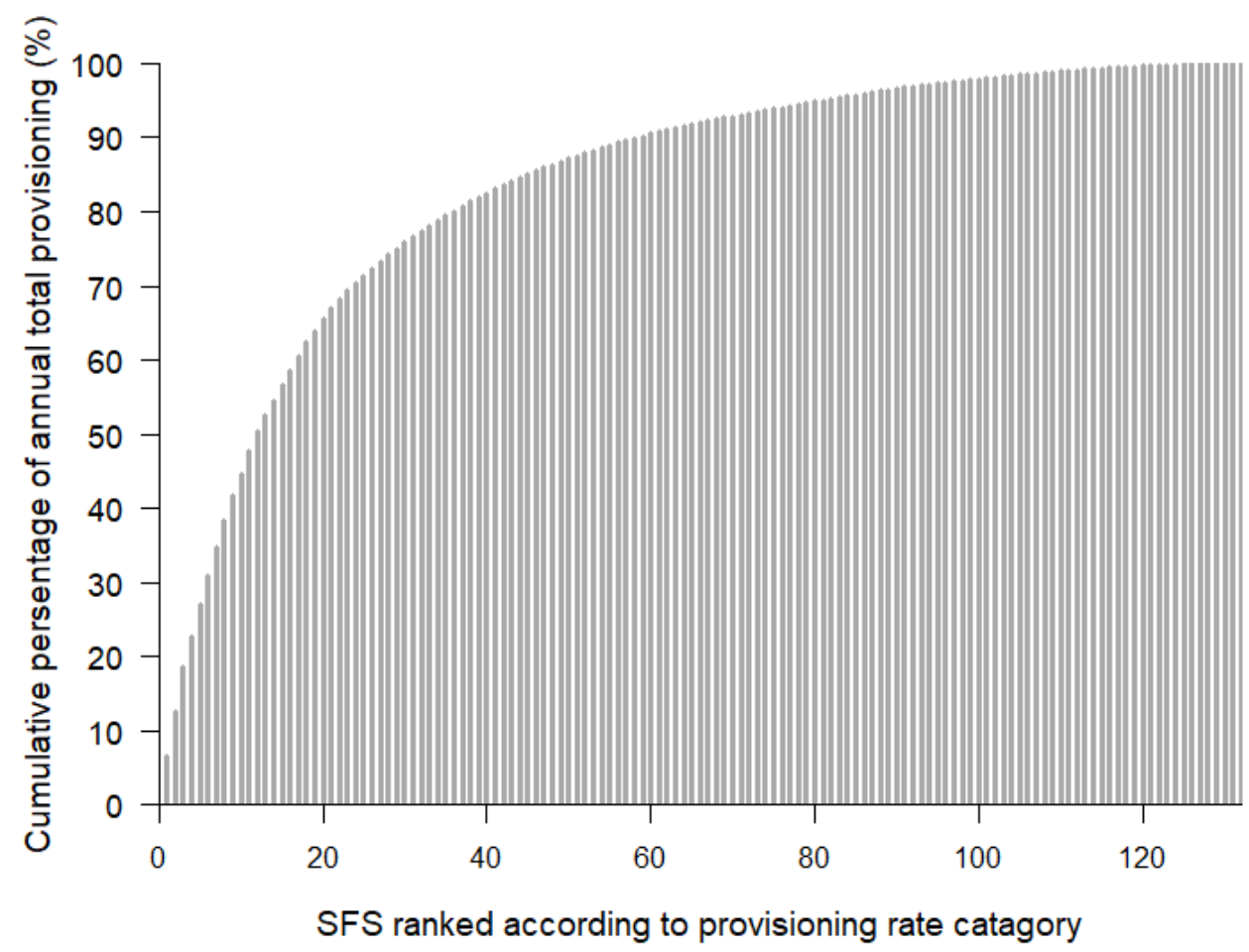

391

392 Appendix 2: Supplementary feeding sites (SFS) ranked according to their annual provisioning rates, 393 from highest to lowest, in relation to the cumulative contribution of each additional site, to the 394 national total annual provisioning rate (expressed as a percentage).

395

396

397

398

399

400

401

402

403

404 


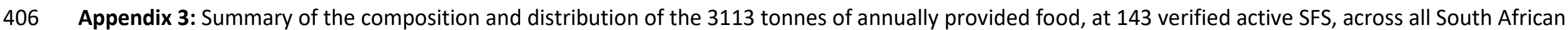
407 provinces. (LP = Limpopo, KZN = KwaZulu Natal, NW = North West, EC = Eastern Cape, GT = Gauteng, MP = Mpumalanga, FS = Freestate, NC = Northern 408 Cape, $\mathrm{WC}=$ Western Cape).

\begin{tabular}{|c|c|c|c|c|c|c|c|c|c|}
\hline Province & $\begin{array}{c}\text { Verified } \\
\text { active sites }\end{array}$ & TOTAL t/y & $\%$ of TOTAL & \% Beef & \% Game & \% Pork & \% Sheep & \% Equine & $\%$ Other \\
\hline LP & 32 & 1198.7 & 38.5 & 35.9 & 27.6 & 30.4 & 4.1 & 0.2 & 1.7 \\
\hline KZN & 51 & 752.4 & 24.2 & 56.4 & 10.9 & 25.3 & 1.6 & 3.7 & 2.1 \\
\hline NW & 16 & 616.5 & 19.8 & 15.0 & 14.6 & 59.9 & 3.8 & 1.4 & 5.3 \\
\hline EC & 21 & 246.8 & 7.9 & 89.1 & 0 & 2.2 & 5.9 & 2.7 & 0.0 \\
\hline GT & 6 & 165.1 & 5.3 & 11.4 & 12.7 & 64.5 & 0.3 & 11.1 & 0.0 \\
\hline MP & 6 & 78.4 & 2.5 & 13.6 & 82.2 & 0.0 & 0.4 & 3.8 & 0.0 \\
\hline FS & 6 & 26.2 & 0.8 & 54.2 & 16.8 & 3.2 & 12.2 & 3.8 & 9.8 \\
\hline NC & 4 & 16.2 & 0.5 & 20.2 & 61.9 & 0.0 & 3.9 & 14.1 & 0.0 \\
\hline WC & 1 & 12.6 & 0.4 & 47.2 & 0.0 & 0.0 & 52.8 & 0.0 & 0.0 \\
\hline
\end{tabular}


Appendix 4: Vulture species home range sizes used for the calculation of SFS range coverage. The maximum buffer radius corresponds to the $95 \%$ Kernel Density Estimates (KDE) for the given species. Only a 90\% KDE was available for bearded vultures. For the minimum buffer size, 50\% KDE was used.

\begin{tabular}{|c|c|c|c|c|c|}
\hline Species & Scientific name & $\begin{array}{c}\text { Average home } \\
\text { range } \\
\left(\mathrm{km}^{2}\right)\end{array}$ & $\begin{array}{l}\text { Maximum } \\
\text { buffer radius } \\
(\mathrm{km})\end{array}$ & $\begin{array}{l}\text { Minimum } \\
\text { buffer radius } \\
(\mathrm{km})\end{array}$ & References \\
\hline Lappet-faced vulture & Torgos tracheliotos & 194813 & 249 & 94 & Garbett, 2018 \\
\hline African white-backed vulture & Gyps africanus & - & $249^{i}$ & $94^{i}$ & Spiegel, Getz, \& Nathan, 2013 \\
\hline Cape vulture & Gyps corprotheres & 110181 & 187 & 56 & Kane et al., 2016 \\
\hline White-headed vulture & Trigonoceps occipitalsis & - & $120^{\mathrm{ii}}$ & $41^{\mathrm{ii}}$ & - \\
\hline Hooded vulture & Necrosyrtes monachus & 3913 & 35 & 10 & Reading et al., 2019 \\
\hline Bearded vulture & Gypaetus barbatus & 286 & 10 & 4 & Krüger, Reid, \& Amar, 2014 \\
\hline
\end{tabular}

413 'Data unavailable, lappet-faced vulture values used here based on literature suggesting similar movement behaviour.

414 ii Data unavailable, average values of all other species for which data was available used. 
BirdLife International and NatureServe (2015). Bird species distribution maps of the world. Version 4.0. BirdLife International, Cambridge, UK and NatureServe, Arlington, USA. Brown, C.J. (1997). Population dynamics of the bearded vulture Gypaetus barbatus in southern Africa. Afri. J. Ecol. 35, 53-63.

Donazar J.A. (1993). Los buitres Ibéricos. Biología y conservación. 1 ed., J.M. Reyero, Madrid.

Kemp, A. \& Begg, K. 2001. Comparison of time-activity budgets and population structure for 18 large-bird species in the Kruger National Park, South Africa. Ostrich 72, 179-184.

Mundy, P., Butchart, D., Ledger, J. \& Piper, S. (1992). The vultures of Africa. Academic Press, London.

Murn, C. \& Botha A. (2018). A clear and present danger: Impacts of poisoning on a vulture population and the effect of poison response activities. Oryx 52, 552-558.

Robertson, A.S. (1984). Aspects of the population dynamics of Cape vultures in the Cape Province. Ostrich 55, 196-206.

Taylor M., Peacock F. \& Wanless R.M. (2015). Eskom Red Data Book of Birds of South Africa, Lesotho and Swaziland. BirdLife South Africa, University of Cape Town and South African National Biodiversity Institute, Johannesburg, South Africa. 


\section{Supplementary material:}

\section{Questionnaire}

Date:

VR_Code (for office use):

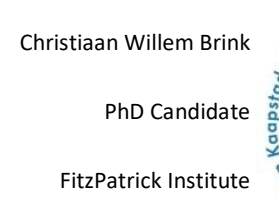

University of Cape Town

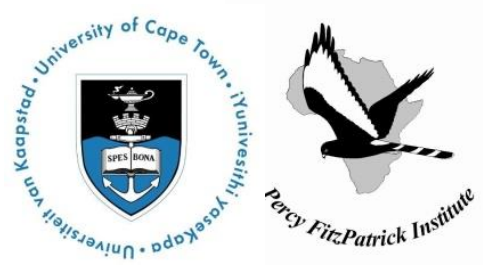

christiaanwillembrink@gmail.com

0817317643

VULTURE RESTAURANT SURVEY:

Hello, my name is Christiaan W. Brink and I am a PhD student at the University of Cape Town researching the contribution of vulture restaurants to vulture conservation in South Africa. I found your contact details on our existing database in relation to a vulture restaurant / feeding site, and would appreciate it if you took part in our survey that will aid vulture conservation and which will ultimately benefit vultures and landowners. Your participation would be appreciated whether you are currently feeding vultures or have stopped doing so.

As part of my thesis I am updating the current database with the information of vulture restaurant managers. This information will not be published or made freely available to the public and will only be distributed to the relevant people in vulture conservation and research (eg. VulPro, EWT, Ezemvelo KwaZulu-Natal wildlife, all of which have contributed to, or is a collaborator on this project). Do you give consent for your information to be shared with the before mentioned people?

\section{Participant agreed (Please remove if you disagree)}

At the same time we would like to get an understanding of what motivates people to run vulture restaurants. Please answer the questions below. Please note that the answers from these questions (excluding the Basic Info) will not be included in the database but rather kept confidential. When the research is published, none of your answers will be linked with your name or name of your farm and so will remain anonymous.

Please note that your participation in this interview is completely voluntary.

Do you agree to participate in this interview?

Participant agreed (Please remove if you disagree)

\section{A. Basic info/demographics}

1. Name:

2. Position/role at the property: (i.e.: owner, manager):

3. Occupation: 
4. Property owner name:

5. Name of property/farm:

6. Vulture restaurant property address:

7. Email:

8. Preferred contact number:

9. Coordinates of Vulture Restaurant (if not available, coordinates of property-please specify the structure for which coordinates are given):

C. Vulture Restaurant (VR):

10. Is the vulture restaurant still active, are you still feeding vultures?

[if closed] :

11. When did you stop putting out food for vultures?

12. What were the reasons why you stopped?

13. When did you start feeding vultures? (year and month if possible)

14. What was the motivation behind establishing and maintaining the vulture restaurant?

15. Please provide as accurate an estimate and description of what is provided at the vulture feeding site as possible: (eg. 2 Adult pigs per year (200-300kg per carcass); $10 \mathrm{~kg}$ of Beef offal per day; 5 new born calves per month; Offal from 50 game carcasses during hunting season). We are fully aware that this may depend on stock losses and be variable but please make an attempt at providing some sort of rough estimate. Number of carcasses provided over the last year might be easiest. If closed please provide an indication of how much you used to feed.

16. Where is/was this food sourced from? (eg. My own property; neighbouring farmers donate; SPCA)

17. In your opinion do carcasses containing lead from spent ammunition pose any potential health threats to vultures (eg. Feeding on animals shot during hunting)? Please highlight chosen answer
a. Yes
b. No
c. I don't know 
18. In your opinion can veterinary drugs present in carcasses have any negative effects on vulture health? Please highlight chosen answer
a. Yes
b. No
c. I don't know

Additional notes: 